\title{
Natural enemies of the maize cob borer, Mussidia nigrivenella (Lepidoptera: Pyralidae) in Benin, West Africa
}

\author{
M. Sétamou ${ }^{1,2}$, F. Schulthess ${ }^{2}$, G. Goergen ${ }^{2}$, \\ H.-M. Poehling ${ }^{3}$ and C. Borgemeister ${ }^{3^{*}}$
}

${ }^{1}$ Texas A\&M University, Agricultural Research and Extension Centre, 2415 East Highway 83, Weslaco, TX 78596-8399, USA: ${ }^{2}$ Plant Health

Management Division, International Institute of Tropical Agriculture, 08 BP 932 Tri Postal, Cotonou, Republic of Benin: ${ }^{3}$ Institute of Plant

Diseases and Plant Protection, University of Hannover, Herrenhäuser Str. 2, 30419 Hannover, Germany

\begin{abstract}
Mussidia nigrivenella Ragonot is a pest of maize cobs in West Africa. It significantly reduces maize yields and grain quality, with quantitative losses of $2-25 \%$ at harvest, and up to $10-15 \%$ indirect losses due to an increase in storage pest infestation levels. Infestation by M. nigrivenella also significantly increased the susceptibility of maize to Aspergillus flavus infection and subsequent aflatoxin contamination. Surveys conducted in different agro-ecological zones of Benin on cultivated and wild host plants during 1994-1997 revealed one egg parasitoid, three larval parasitoids and one pupal parasitoid attacking M. nigrivenella. Egg parasitism was scarce on all host plants sampled and in all four agro-ecological zones. Parasitism by larval and pupal parasitoids was usually less than $10 \%$, and varied with host plant species. Both larval and pupal parasitoids were rare or absent in cultivated maize fields. The solitary chalcidid pupal parasitoid, Antrocephalus crassipes Masi, was the predominant species, contributing approximately $53 \%$ of the observed mortality. Logistic regression analysis indicated that this parasitoid was more prevalent on fruits of Gardenia spp. (Rubiaceae) than on the other host plant species including maize used by M. nigrivenella, and was most abundant between February and September. The differences in parasitoid diversity and parasitism between Benin and other regions suggest that there are opportunities for biological control through introduction of exotic parasitoids or using the 'new association' approach, which uses natural enemies of closely related host species that occupy similar ecological niches to the target pest.
\end{abstract}

\section{Introduction}

In West Africa, Mussidia nigrivenella Ragonot (Lepidoptera: Pyralidae) is a pest of cotton bolls (Staeubli, 1977; Silvie, 1990) and maize cobs (Moyal, 1988; Bosque-Pérez \& Mareck, 1990;

* Author for correspondence

Fax: +49511 7623015

E-mail: borgemeister@ipp.uni-hannover.de
Moyal \& Tran, 1991; Gounou et al., 1994; Ndemah et al., 2001). Although more than half of the cobs in the field are usually infested, reported yield losses varied from 5 to $25 \%$ (Whitney, 1970; Moyal \& Tran, 1991; Sétamou et al., 2000a). Mussidia nigrivenella continues to feed on maize grains in storage leading to an additional 5\% in yield loss (Sétamou, 1996). However, more importantly, its damage also predisposes maize to pre- and post-harvest infestations by storage beetles, infection by Aspergillus flavus Link (Hyphomycetes) and 
subsequent aflatoxin contamination (Sétamou et al., 1998). Increases of up to $15 \%$ of yield loss due to storage beetles were reported in the presence of $M$. nigrivenella damage (Sétamou, 1996).

Though described from East, southern and Central Africa from wild hosts (Sorauer, 1925; Janse, 1941; LePelley, 1959; Bouyckx, 1962; Entwistle, 1972; Waiyaki, 1973), M. nigrivenella has never been reported as a pest of annual crops outside western Africa (i.e. West Africa and Cameroon, in this study). Either eastern (i.e. East and southern) African populations do not recognize these plants as hosts and/or M. nigrivenella is under biological control in its wild habitats, thereby preventing it from moving into crop fields. This would open up opportunities for expanding the geographical range of natural enemy species to areas where they do not exist yet, or for using the 'new association' approach to biological control. The first approach has been proposed by several authors as a solution to lepidopterous pest problems on maize and sugarcane in Africa and has been variously termed 'redistribution' or 'classical biological control' (Rao, 1965; Mohyuddin \& Greathead, 1970; Conlong, 1997; Schulthess et al., 1997). For example, a coastal strain of the larval parasitoid Cotesia sesamiae (Cameron) (Hymenoptera: Braconidae) from Kenya was released and established on Sesamia calamistis Hampson (Lepidoptera: Noctuidae) in southern Benin (Schulthess et al., 1997); the larval parasitoid Sturmiopsis parasitica Curran (Diptera: Tachinidae) was introduced from western into South Africa, where it does not occur, and released against Eldana saccharina Walker (Lepidoptera: Pyralidae) on sugarcane (D. Conlong, South African Sugar Experimental Station, Durban, South Africa, personal communication). Similarly, it is planned to introduce the western African egg parasitoid species Telenomus isis Polaszek (Hymenoptera: Scelionidae) into eastern Africa for control of Busseola fusca Fuller (Lepidoptera: Noctuidae). Success in the longer run thus depends largely on the permanent establishment of an exotic biological control agent in a new area.

The 'new association' approach to biological control uses natural enemies of closely related host species occupying similar ecological niches, that do not share a common evolutionary relationship with the target pest (Hokkanen \& Pimentel, 1989). Thus, in our case, species of primary interest would be other Mussidia species and their parasitoids occurring in eastern Africa that attack the same wild host plant species that $M$. nigrivenella feeds on in western Africa.

Janse (1941) described eight Mussidia spp., five from the African mainland, two from Madagascar and Réunion, and one from Asia. However, with the exception of M. nigrivenella, which was the only species identified by the author in West Africa so far, no information is available about the biology and ecology of other Mussidia spp. The first steps when considering either of the two biological control approaches is the establishment and comparison of a list of host plants and associated natural enemies of Mussidia spp. in the different African regions. Moyal (1988) compiled a list of host plants published by various authors but a detailed list is available only for the Republic of Benin (Sétamou et. al., 2000b). The results of several country-wide surveys have revealed that $M$. nigrivenella feeds on at least 20 plant species from 11 different families, most of them trees and bushes. However, less information exists on the natural enemies attacking M. nigrivenella. Surveys conducted on maize in Ghana (Gounou et al., 1994) and Benin (Shanower et al., 1991) yielded no larval or pupal parasitoids. Likewise, Moyal (1988) working on maize in Côte d'Ivoire found only a few unidentified trichogrammatid and scelionid egg parasitoids, whereas in Cameroon, five parasitoid species were obtained that emerged from parasitized larva and pupae (Nonveiller, 1984; Ndemah et al., 2001). However, all these collections were restricted to maize, which owing to its ephemeral nature is a rather unstable habitat for both borers and their natural enemies, and nothing is known about the natural enemy complex attacking $M$. nigrivenella on wild and especially annual host plants. Parasitoids often show a clear preference for particular food plants when foraging for polyphagous insect hosts (Taylor, 1932; Vinson, 1981; Benerey et al., 1997), and maize and cotton, the principal hosts, may not be preferred host plants. Also, as maize is highly susceptible to borer attack and subsequent $A$. flavus infection and aflatoxin contamination, and damaged plants cannot be sold as green maize, reduction of pest populations is best achieved on the wild hosts.

In this study an attempt was made to catalogue the natural enemies of $M$. nigrivenella occurring on cultivated and wild hosts in different agro-ecological zones of Benin. A detailed study of the abundance of both M. nigrivenella and its natural enemies on selected host plants was undertaken over a two year period. Similar attempts to identify the host plant range and natural enemies' complexes of Mussidia spp. are underway in East Africa.

\section{Materials and methods}

A preliminary 10 day survey of pod and fruit-bearing herbaceous plants and shrubs, considered potential host plants of $M$. nigrivenella (sampled in a random manner) was carried out in all four agro-ecological zones of Benin during autumn 1991. The zones were, from south to north, the Forest Savanna Mosaic, the Southern Guinea Savanna, the Northern Guinea Savanna, and the Sudan Savanna with highest annual rainfall of $1400 \mathrm{~mm}$ in the Forest Savanna Mosaic and lowest rainfall of $900 \mathrm{~mm}$ in the Sudan Savanna. Further countrywide surveys conducted from July 1993 to December 1995 at three-monthly intervals, and monthly from January 1996 to December 1997 concentrated on tree species (see Sétamou et al., 2000b). Data from maize fields sampled throughout the country or from on-station experiments were also included (Sétamou \& Schulthess, 1995; Sétamou et al., 1995, 1998, 1999, 2000a,b). Maize and all encountered wild plant species with fruiting structures, including known host plants, were sampled. Whenever possible, a sample of 20 fruits was taken. All collected fruits were first visually examined for eggs or first instar larvae, and then dissected for borers. Because the immature stages are difficult to identify, eggs, larvae and/or pupae collected from the different hosts were brought back to the laboratory for examination. The eggs were incubated at $26 \pm 2{ }^{\circ} \mathrm{C}$ and $65 \pm 5 \% \mathrm{rh}$, on moistened tissue paper until larval or parasitoid emergence. The emerged larvae as well as the field-collected larvae were reared on jackbean pods, Canavalia ensiformis (L.) DC. (Fabaceae), following the protocol developed by Sétamou et al. (1999), until pupation or parasitoid emergence. Pupae were kept individually in $30 \mathrm{ml}$ transparent plastic capsules, until moth or parasitoid emergence. Parasitoid species were identified at the insect museum of the International Institute of Tropical Agriculture (IITA), Calavi, Republic of Benin, and Mussidia spp. using the key prepared by Moyal (1988). 
A sample consisted of all immature stages of M. nigrivenella (i.e. eggs, larvae, or pupae) collected in a given field for crops or on a given wild host plant species during each survey or field study, respectively. Only hosts with emerging parasitoids were considered as being 'parasitized', thus leading to an underestimation of the impact of natural enemies since hosts killed by parasitoids but not yielding any parasitoid were not considered as dying from parasitoid-related mortality. Percentage parasitism, calculated separately for each of the three immature stages and per host plant species, was expressed as the number of 'parasitized hosts' (hosts yielding parasitoids) compared to the total number of $M$. nigrivenella in the respective developmental stage.

For the 1996/97 survey data on wild hosts, backward stepwise logistic regression models (Hosmer \& Lemeshow, 1989) were used to evaluate the effects of sampling year and month and the different host plants as predictors of the level of parasitism of the different developmental stages of M. nigrivenella. All predictor variables were coded as dummy variables, i.e. 0 for absence and 1 for presence. Hence, for months 11 dummy variables were used, and three dummy variables for host plants, corresponding to the four host plants from which larval and/or pupal parasitoids were obtained during the surveys. Analyses were conducted using the PROC LOGISTIC of SAS (SAS institute, 1996), and the fit of the models was determined using the $\chi^{2}$ values (Hosmer \& Lemeshow, 1989).

\section{Results}

\section{Species composition and distribution of parasitoids}

Only five parasitoid species were found on immature stages of M. nigrivenella. With a few exceptions they were all obtained from $M$. nigrivenella collected from tree species which are common in the savannahs, and especially the Southern Guinea Savannah but are rare in the Forest Savannah Mosaic in the south (table 1). The Telenomus sp.
(Hymenoptera: Scelionidae) was the only egg parasitoid and emerged mainly from samples collected from fruits of Parkia biglobosa (Jacq.) Benth. (Mimosaceae). No egg parasitoids were recorded from maize cobs. The larval parasitoids Bracon sesamiae Cameron and Apanteles sp. (both Hymenoptera: Braconidae) were obtained from maize and some tree species. About $65 \%$ of the larval parasitism was due to B. sesamiae, but from maize only seven specimens were collected during all surveys. A few individuals of a Perilampus sp. (Hymenoptera: Perilampidae) also emerged from $M$. nigrivenella larvae.

Only one parasitoid species, Antrocephalus crassipes Masi (Hymenoptera: Chalcididae) was obtained from pupae (table 1). This solitary parasitoid emerged mainly from pupae collected from fruits of wild host plant species with one specimen only from maize in the Northern Guinea Savannah. Antrocephalus crassipes emerged from pupae collected in the Southern Guinea Savannah, Northern Guinea Savannah, and the Sudan Savannah, but not from samples collected in the Forest Savannah Mosaic in the south (table 1). Across all host plant species, A. crassipes was the predominant parasitoid species, accounting for approximately $53 \%$ of all emerged parasitoids (fig. 1).

No parasitoids were recorded from other herbaceous plants such as the cover crops, jackbean, C. ensiformis and velvetbean, Mucuna pruriens DC. (Fabaceae).

\section{Incidence and levels of parasitism}

Egg parasitism was in general extremely low $(<0.1 \%)$ and thus not included in the subsequent analyses. Mean larval and pupal parasitism, and total parasitism across all sampling occasions on the different host plant species are presented in fig. 1. Larval parasitism ranged from $<0.5 \%$ on Ximenia americana L. (Olacaceae) and the baobab tree Adansonia digitata L. (Bombacaceae) to $4-5 \%$ on Parkia biglobosa and Gardenia spp. (Rubiaceae). A similar trend was observed for pupal parasitism, with a highest

Table 1. Summary of parasitoid species recovered from Mussidia nigrivenella collected on various host plants in different agroecological zones in Benin, 1994-1997.

\begin{tabular}{|c|c|c|c|}
\hline Parasitoid species & Families & Host plants & Agro-ecological zones ${ }^{3}$ \\
\hline $\begin{array}{l}\text { Egg parasitoid } \\
\text { Telenomus sp. }\end{array}$ & Scelionidae & Parkia biglobosa (Jacq.) Benth. (Mimosaceae) & SGS, NGS \\
\hline Larval parasitoids & & & \\
\hline Bracon sesamiae Cameron & Braconidae & $\begin{array}{l}\text { Adansonia digitata L. (Bombacaceae) } \\
\text { Gardenia spp. (Rubiaceae) } \\
\text { Parkia biglobosa (Jacq.) Benth. (Mimosaceae) } \\
\text { Ximenia americana L. (Olacaceae) } \\
\text { Zea mays L. (Poaceae) }\end{array}$ & $\begin{array}{l}\text { SGS } \\
\text { SGS, NGS, SS } \\
\text { SGS, NGS } \\
\text { NGS } \\
\text { FSM, SGS }\end{array}$ \\
\hline Apanteles sp. & Braconidae & $\begin{array}{l}\text { Gardenia spp. (Rubiaceae) } \\
\text { Parkia biglobosa (Jacq.) Benth. (Mimosaceae) } \\
\text { Zea mays L. (Poaceae) }\end{array}$ & $\begin{array}{l}\text { NGS, SS } \\
\text { SGS, NGS, SS } \\
\text { SGS, NGS }\end{array}$ \\
\hline Perilampus sp. ${ }^{1}$ & Perilampidae & $\begin{array}{l}\text { Parkia biglobosa (Jacq.) Benth. (Mimosaceae) } \\
\text { Zea mays L. (Poaceae) }\end{array}$ & SGS \\
\hline \multicolumn{4}{|l|}{ Pupal parasitoid } \\
\hline Antrocephalus crassipes Masi & Chalcididae & $\begin{array}{l}\text { Gardenia spp. (Rubiaceae) } \\
\text { Parkia biglobosa (Jacq.) Benth. (Mimosaceae) } \\
\text { Ximenia americana L. (Olacaceae) } \\
\text { Zea mays L. (Poaceae) })^{2}\end{array}$ & $\begin{array}{l}\text { NGS, SS } \\
\text { SGS, NGS, SS } \\
\text { NGS, SS } \\
\text { NGS }\end{array}$ \\
\hline
\end{tabular}

${ }^{1}$ Parasitoid of, or hyperparasitoid on many lepidopterous larvae.

${ }^{2}$ Collected on one occasion in late harvested maize fields.

${ }^{3}$ FMS, Forest Savannah Mosaic; SGS, Southern Guinea Savannah; NGS, Northern Guinea Savannah; SS, Sudan Savannah. 

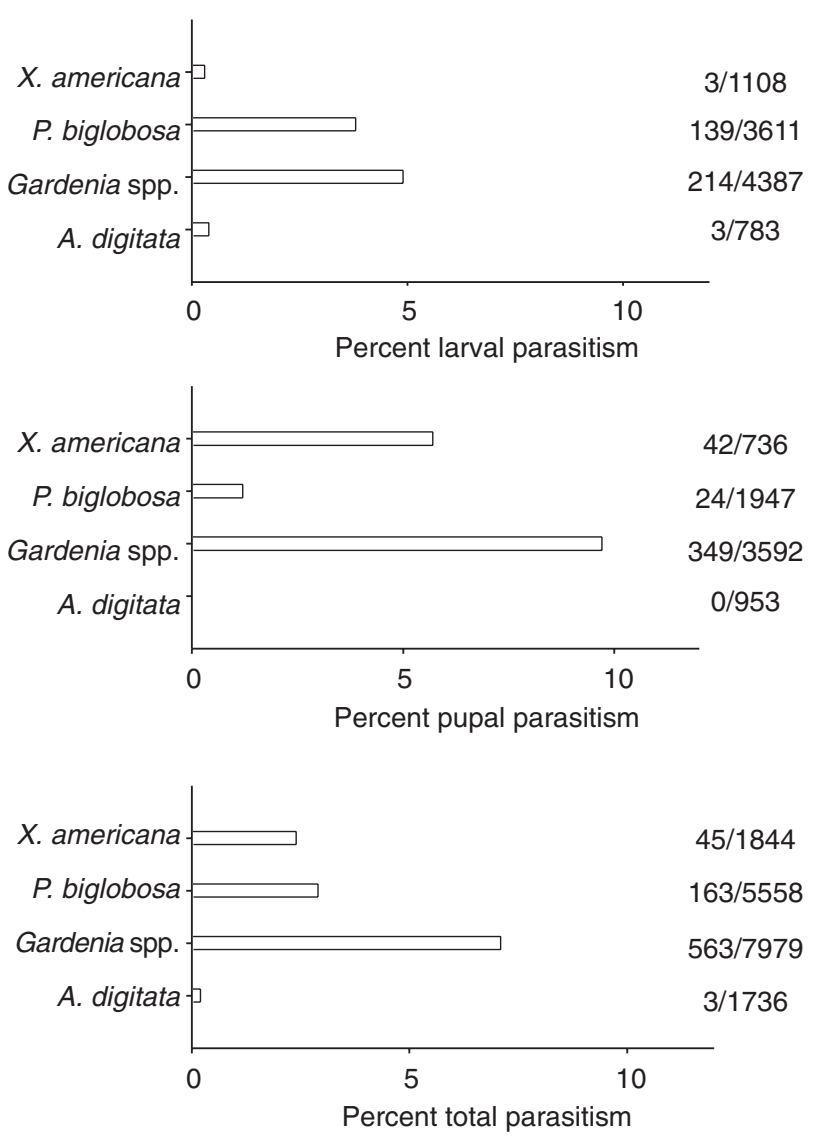

Fig. 1. Mean larval and pupal parasitism, and total parasitism of Mussidia nigrivenella across all sampling occasions on four host plant species (Benin, January 1996 to December 1997).

mean level of about $10 \%$ on Gardenia spp., but no specimens were recovered from $A$. digitata. Total parasitism ranged from $0.2 \%$ on $A$. digitata to $7.1 \%$ on Gardenia spp.; on maize it was $<0.1 \%$. The incidence of larval and pupal parasitism varied with host plant species and time, thus reflecting the phenology of fruit setting of individual host plant species, and the pattern was similar in both years (figs 2 and 3). On $X$ americana, larval parasitoids were recorded only in September, and the pupal parasitoid Antrocephalus crassipes was found in November and December (figs 2 and 3). Levels of pupal parasitism were also low on P. biglobosa, but larval parasitism was recorded throughout the whole fruiting period, with higher values towards the end (figs 2 and 3). On Gardenia spp., both parasitized larvae and pupae were found throughout the whole year, but levels of parasitism varied with time (figs 2 and 3).

The logistic regression models yielded a clear association between both larval and pupal parasitism and host plants (tables 2 and 3). Likewise, time of the year had a significant impact on the levels of parasitism. No significant effect of year of sampling was observed for both larval and pupal parasitism. The fit of both models was good $\left(\chi^{2}=3.41, \mathrm{DF}=\right.$ $4, P=0.49$ and $\chi^{2}=4.90, \mathrm{DF}=7, P=0.67$ for larval and pupal parasitism, respectively). Larval parasitism was most likely
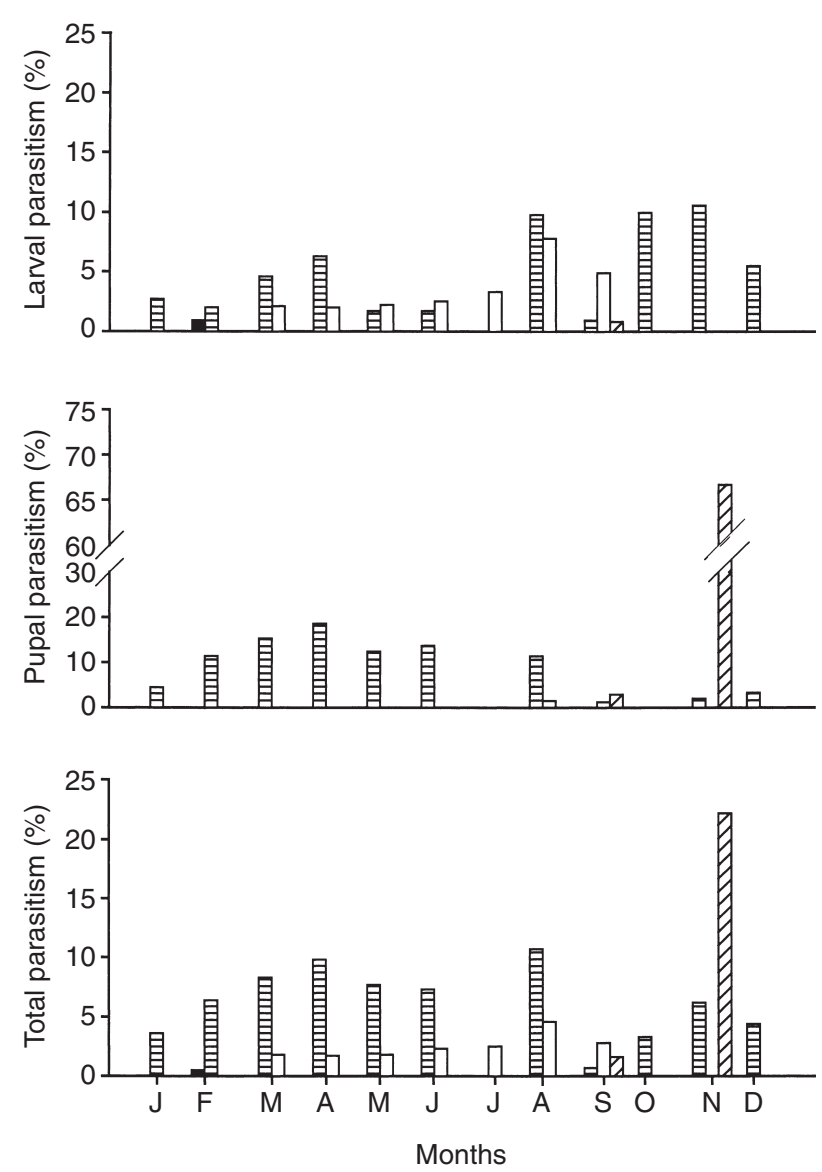

Fig. 2. Parasitism of Mussidia nigrivenella by larval and pupal parasitoids and total parasitism on fruits of four host plant species (Benin, January to December 1996). $\mathbf{\square}$, Adansonia digitata; 目, Gardenia spp.; $\square$, Parkia biglobosa; $\boldsymbol{\varnothing}$, Ximenia americana.

to occur when larvae were collected from P. biglobosa and Gardenia spp., whereas the other host plant species made no significant contribution (table 2, fig. 1). The high odds ratios for Gardenia spp. and P. biglobosa (22.9 and 16.7, respectively) indicated a preference of the larval parasitoids for larvae on these host plant species (table 2). Larval parasitism was significantly higher between August and November than during the other months of the year (table 2, figs 2 and 3).

The likelihood of parasitism of Mussidia nigrivenella pupae by $A$. crassipes was significantly higher on Gardenia spp. than on other host plant species (table 3). The high odds ratio for Gardenia spp. (9.7) indicated that pupae on this host plant species were about ten times more likely to be parasitized by $A$. crassipes as those on the other host plant species. Likewise, the occurrence of A.crassipes was significantly higher between February and September, with the likelihood of parasitism being three to four times higher during this period than between October and January.

\section{Discussion}

Only five out of the 20 host plants known to be attacked by M. nigrivenella (Moyal, 1988; Sétamou et al., 1999) yielded parasitoids. The differences in both parasitoid diversity and 

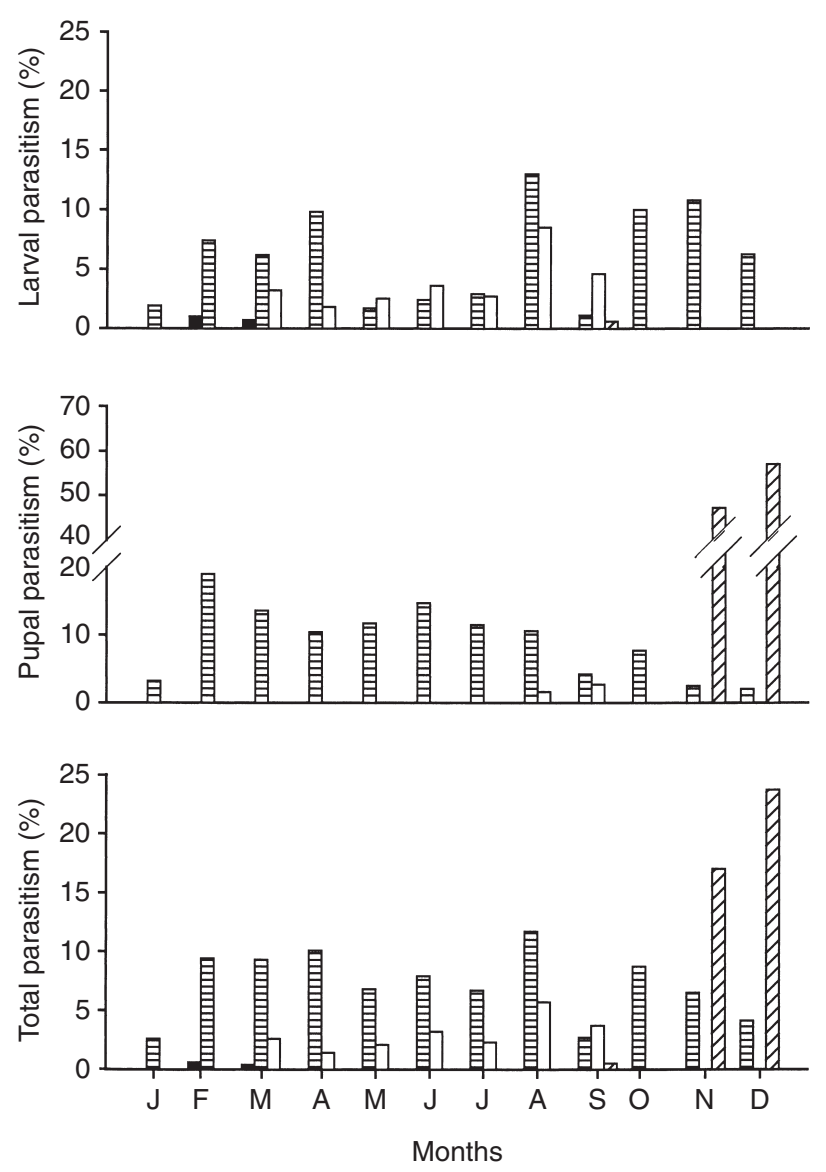

Fig. 3. Parasitism of Mussidia nigrivenella by larval and pupal parasitoids and total parasitism on fruits of four host plant species (Benin, January to December 1997). $\mathbf{\square}$, Adansonia digitata; 目, Gardenia spp.; $\square$, Parkia biglobosa; $\gg$, Ximenia americana.

abundance between annual herbaceous plants and trees, as well as between the different tree species were striking. However, some of the most suitable and preferred annual host plants such as maize, jackbean and velvetbean are exotic to Africa and may not produce the necessary chemical and physical clues needed by natural enemies to detect their insect hosts (see Smith et al., 1993; Janz \& Nylin, 1997). A similar situation is found among the natural enemy complex of the maize pest E. saccharina on sugarcane in South Africa. On its most common natural host plant, the sedge Cyperus papyrus L. (Cyperaceae), the natural enemy fauna is quite diverse and rates of parasitism range between 10 and $40 \%$ (Conlong, 1990, 1994). However, these parasitoid species rarely attack E. saccharina on sugarcane in adjacent fields. Direct accessibility of the host very likely also plays a major role. Mussidia nigrivenella spends most of its life cycle inside cobs, seed pods or fruit, and most of the plant species show no external feeding damage until shortly before pupation, when the borer produces an exit hole. As a result, larval parasitism is generally considerably lower than pupal parasitism, and B. sesamiae, the most common parasitoid attacking larvae, belongs to the drill-and-sting guild (Smith et al., 1993).

In our study M. nigrivenella larvae were also occasionally parasitized by a Perilampus sp., but species of this genus can be either primary or hyperparasitoids (Subbiah, 1987), and are thus of limited use for biological control. The duration of fruit formation and the availability of fruits may also affect the population dynamics of both the pest and natural enemies. In contrast to maize, many wild hosts have a nondeterminant growth pattern. They produce new fruits during an extended period, which are mostly not harvested and remain on the plants until they drop. Thus, they allow several generations of $M$. nigrivenella to develop per year (Sétamou et al., 2000b), and thereby increase the likelihood of parasitism. In this respect, wild woody host plants represent a far more stable habitat than rather ephemeral maize plants. This, however, does not explain the differences in parasitism between tree species, and the fact that on most species, parasitoids are absent. According to Hare \& Luck (1991), and Karowe \& Schoonhoven (1992) these differences may also reflect the suitability of herbivorous hosts for the developing parasitoid, which may vary with the host plant fed upon.

The pupal parasitoid A. crassipes was the main parasitoid species and was found only on wild host plants. It occurred only in the three northern agro-ecological zones, which reflects the diversity and abundance of wild host plants in these zones (Sétamou et al., 2000b). High levels of parasitism were recorded between February and September, i.e. before and during cob formation in maize. Thus in those regions, biological control activity on wild host plants may have an impact on pest infestations on crops such as maize and cotton. By contrast, in the south, the most common host is maize and to a lesser extent jackbean and velvetbean (Sétamou et al., 2000b) on which parasitoids were scarce although both jackbean and velvetbean are highly suitable for growth and development of $M$. nigrivenella (Sétamou et al., 1999). In Cameroon, the natural enemy fauna on maize is much more diverse than in West Africa. Nonveiller (1984) reported Hemimetopius anguilitarsis Benoit and Syzeuctus sp.

Table 2. Logistic regression analysis of the effect of sampling months and host plant species on larval parasitism levels of Mussidia nigrivenella.

\begin{tabular}{lcccrcc}
\hline Variable & DF & Parameter estimate & SE & Wald $\chi^{2}$ & $P$-value & Odds ratio \\
\hline Intercept & 1 & -6.05 & 0.42 & 212.33 & $<0.01$ & - \\
January & 1 & -0.81 & 0.25 & 10.95 & $<0.01$ & 0.44 \\
May & 1 & -0.69 & 0.23 & 8.97 & $<0.01$ & 0.50 \\
August & 1 & 0.77 & 0.16 & 23.03 & $<0.01$ & 2.17 \\
October & 1 & 0.72 & 0.30 & 5.60 & 0.02 & 2.05 \\
November & 1 & 0.78 & 0.36 & 4.66 & 0.03 & 2.18 \\
Gardenia spp. & 1 & 3.13 & 0.42 & 55.70 & $<0.01$ & 22.92 \\
Parkia biglobosa & 1 & 2.81 & 0.42 & 45.07 & $<0.01$ & 16.67 \\
\hline
\end{tabular}


Table 3. Logistic regression analysis of the effect of sampling months and host plant species on levels of parasitism of Mussidia nigrivenella pupae by Antrocephalus crassipes.

\begin{tabular}{lcccrcc}
\hline Variable & DF & Parameter estimate & SE & Wald $\chi^{2}$ & P-value & Odds ratio \\
\hline Intercept & 1 & -5.44 & 0.31 & 307.27 & $<0.01$ & - \\
February & 1 & 1.32 & 0.19 & 48.60 & $<0.01$ & 3.75 \\
March & 1 & 1.40 & 0.18 & 61.90 & $<0.01$ & 4.06 \\
April & 1 & 1.43 & 0.19 & 57.06 & $<0.01$ & 4.18 \\
May & 1 & 1.14 & 0.21 & 30.60 & $<0.01$ & 3.14 \\
June & 1 & 1.30 & 0.34 & 14.79 & $<0.01$ & 3.67 \\
August & 1 & 1.13 & 0.27 & 18.05 & $<0.01$ & 3.10 \\
September & 1 & 1.06 & 0.34 & 9.90 & $<0.01$ & 2.89 \\
Gardenia spp. & 1 & 2.27 & 0.28 & 65.13 & $<0.01$ & 9.72 \\
\hline
\end{tabular}

(both Hymenoptera: Ichneumonidae), and Ndemah et al. (2001) obtained A. crassipes, B. sesamiae and species of the Tetrasticus atriclavus Waverston complex (Hymenoptera: Eulophidae), which are both primary parasitoids and hyperparasitoids, from larvae and/or pupae of M. nigrivenella. The latter were the most common but rates of parasitism were generally below 10\%. According to Polaszek (1998) the complex includes six species. As the use of facultative hyperparasitoids in biological control is highly controversial (Ehler, 1979; Weseloh et al., 1979), further studies are required to clarify the taxonomy and biology of these species before any conclusions about their status as candidates for biological control can be drawn. In the present study, egg parasitism was in general $<0.1 \%$, and was zero on maize, whereas in the savannahs of Côte d'Ivoire, Moyal (1988) found up to $20 \%$ parasitism of M. nigrivenella eggs on maize.

The difference in parasitoid diversity between West Africa and Cameroon suggests that there are local opportunities for biological control. If in Cameroon the trends follow the same as in Benin, an even higher parasitoid species diversity can be expected on wild hosts than annual crops. Furthermore, in a recent survey in the coastal region and Lake Victoria area of Kenya, Mussidia spp. were commonly found on some wild host plant species (F. Schulthess, unpublished data). Further surveys in the different regions of Africa are planned with the aim of identifying the natural enemy complexes on various wild host plant species. Because of the exceedingly cryptic larval feeding behaviour of Mussidia spp., emphasis will be given to finding egg and pupal parasitoids. Promising candidates will be taken to West Africa for evaluation in the laboratory before release into the wild, in areas with a high diversity and density of alternative host plants.

\section{Acknowledgements}

The authors wish to thank Pascal Gbelissanon, E. Hountohotegbe and R. Codjovi for technical assistance. Special thanks also to M. Weichert and S. Korie for statistical advice. The research was supported by IITA's Maize Health Management Project, funded by the International Fund of Agricultural Development (IFAD). M. Sétamou was additionally supported by a grant of the German Academic Exchange Service (DAAD).

\section{References}

Benerey, B., Denno, R.F. \& Kaiser, L. (1997) The influence of plant species on attraction and host acceptance in Cotesia glomerata (Hymenoptera: Braconidae). Journal of Insect Behaviour 10, 619-630.

Bosque-Pérez, N.A. \& Mareck, J.H. (1990) Distribution and species composition of lepidopterous maize borers in southern Nigeria. Bulletin of Entomological Research 80, 363-368.

Bouyckx, E.J.E. (1962) Précis des maladies et des insectes nuisibles rencontrés sur les plantes cultivées au Congo, au Rwanda et au Burundi. 708 pp. INEAC.

Conlong, D.E. (1990) A study of pest-parasitoid relationship in natural habitats: an aid toward the biological control of Eldana saccharina (Lepidoptera: Pyralidae). Proceedings of the South African Sugar Technology Association 64, 111-115.

Conlong, D.E. (1994) Host parasitoid interactions of Eldana saccharina (Lepidoptera: Pyralidae) in Cyperus papyrus. Unpublished PhD thesis, University of Natal, Republic of South Africa.

Conlong, D.E. (1997) Biological control of Eldana saccharina Walker in South African sugarcane: constraints identified from 15 years of research. Insect Science and its Application 17, 69-78.

Ehler, L.E. (1979) Utility of facultative secondary parasites in biological control. Environmental Entomology 8, 829-832.

Entwistle, P.F. (1972) Pests of cocoa. 779 pp. Longman.

Gounou, S., Schulthess, F., Shanower, T., Hammond, W.H.O., Braima, J., Cudjoe, A.R., Adjakloe, R., Antwi, K.K. \& Olaleye, I. (1994) Stem and ear borers of maize in Ghana. Plant Health Management Research Monograph 4, International Institute of Tropical Agriculture, Ibadan, Nigeria.

Hare, J.D. \& Luck, R.F. (1991) Indirect effects of citrus cultivars on life history parameters of a parasitic wasp. Ecology 72, 1576-1585.

Hokkanen, H.M.T. \& Pimentel, D. (1989) New association approach in biological control: theory and practice. Canadian Entomologist 121, 829-840.

Hosmer, D.W. \& Lemeshow, S. (1989) Applied logistic regression. 2nd edn. 392 pp. New York, John Wiley \& Sons.

Janse, A.J.T. (1941) Contribution to the study of the Phycitinae (Pyralidae: Lepidoptera) part 1. Journal of the Entomological Society of South Africa 4, 134-166. 
Janz, N. \& Nylin, S. (1997) The role of female search behaviour in determining host plant range in plant feeding insects: a test of the information processing hypothesis. Proceedings of the Royal Society of London 264, 701-707.

Karowe, D.N. \& Schoonhoven, L.M. (1992) Interactions between three trophic levels: the influence of host plant on performance of Pieris brassicae and its parasitoid, Cotesia glomerata. Entomologia Experimentalis et Applicata 62, 241-251.

LePelley, R.H. (1959) Agricultural insects of East Africa. 307 pp. East Africa High Commission, Nairobi, Kenya.

Mohyuddin, A.I. \& Greathead, D.J. (1970) An annotated list of the parasites of graminaceous stemborers in east Africa, with a discussion of their potential in biological control. Entomophaga 15, 241-274.

Moyal, P. (1988) Les foreurs du maqs en zone des savanes en Côte d'Ivoire. 367 pp. Collection Etudes et Thèses, Editions de l'ORSTOM, Paris.

Moyal, P. \& Tran, M. (1991) Cob borer Mussidia nigrivenella (Lepidoptera; Pyralidae) of maize in Ivory Coast. II Ecological data. Insect Science and its Application 12, 215-223.

Ndemah, R., Schulthess, F., Poehling, H.-M. \& Borgemeister, C. (2001) Natural enemies of lepidopterous borers on maize and elephant grass in the forest zone of Cameroon with special reference to Busseola fusca (Fuller) (Lepidoptera: Noctuidae). Bulletin of Entomological Research 91, 205-212.

Nonveiller, G. (1984) Catalogue des insectes au Cameroun d'intérêt agricole. 210 pp. Institut pour la Protection des Plantes, Mémoires XV, Beograd.

Polaszek, A. (1998) African cereal stemborers; economic importance, taxonomy, natural enemies and control. 530 pp. CAB International in association with the ACP-EU Technical Centre for Agricultural and Rural Co-operation, CTA, Ede, The Netherlands.

Rao, V.P. (1965) Natural enemies of rice stem-borers and allied species in various parts of the world and possibilities of their use in biological control of rice stem-borers in Asia. Commonwealth Institute of Biological Control Technical Bulletin 6, 1-68.

SAS Institute (1996) SAS user's guide, statistics. SAS Institute, Cary, North Carolina.

Schulthess, F., Bosque-Perez, N.A., Chabi-Olaye, A., Gounou, S., Ndemah, R. \& Goergen, G. (1997) Exchange of natural enemies of lepidopteran cereal stemborers between African regions. Insect Science and its Application 17, 97-108.

Sétamou, M. (1996) Ecology of the insect pests of maize with special reference to Mussidia nigrivenella (Lepidoptera: Pyralidae) and the interaction with the aflatoxin producing fungus Aspergillus flavus. MSc thesis, University of Cape Coast, Ghana.

Sétamou, M. \& Schulthess, F. (1995) The influence of egg parasitoids belonging to the Telenomus busseolae (Hymenoptera: Scelionidae) species complex on Sesamia calamistis (Lepidoptera: Noctuidae) populations in maize fields in Southern Benin. Biocontrol, Science and Technology 5, 69-81.

Sétamou, M., Schulthess, F., Bosque-Pérez, N.A. \& ThomasOdjo, A. (1995) The effect of stem and ear borers on maize subjected to different nitrogen treatments. Entomologia Experimentalis et Applicata 77, 205-210.
Sétamou, M., Cardwell, K.F., Schulthess, F. \& Hell, K. (1998) Effect of insect damage to maize ears, with special reference to the earborer Mussidia nigrivenella, on Aspergillus flavus infection and aflatoxin production in preharvest maize in the Republic of Benin. Journal of Economic Entomology 91, 433-433.

Sétamou, M., Schulthess, F., Poehling, H.-M. \& Borgemeister, C. (1999) Effects of different host plants on the bionomics of Mussidia nigrivenella Ragonot (Lepidoptera: Pyralidae). Bulletin of Entomological Research 89, 465-471.

Sétamou, M., Schulthess, F., Poehling, H.-M. \& Borgemeister, C. (2000a) Monitoring and modeling of field infestation and damage by the maize ear borer Mussidia nigrivenella Ragonot (Lepidoptera: Pyralidae) in Benin, West Africa. Journal of Economic Entomology 93, 650-657.

Sétamou, M., Schulthess, F., Poehling, H.-M. \& Borgemeister, C. $(2000 \mathrm{~b})$ Host plants and population dynamics of the cob borer Mussidia nigrivenella Ragonot (Lepidoptera: Pyralidae) in Benin. Journal of Environmental Entomology 29, 516-524.

Shanower, T., Schulthess, F. \& Gounou, S. (1991) Distribution and abundance of some stem and cob borers in Benin. Plant Health Management Research Monograph 1, International Institute of Tropical Agriculture, Ibadan, Nigeria.

Silvie, P. (1990) Mussidia nigrivenella Ragonot (Pyralidae, Phycitinae): un ravageur mal connu du cotonnier. Coton et Fibres Tropicales 45, 323-333.

Smith, J.W. Jr., Wiedenmann, R.N. \& Overholt, W.A. (1993) Parasites of lepidopteran stemborers of tropical gramineous plants. 89 pp. Nairobi, ICIPE Science Press.

Sorauer, P. (1925) Handbuch der Pflanzenkrankheiten. 360 pp. Berlin, Paul Parey Verlag.

Staeubli, A. (1977) Contribution à l'étude de Cryptophlebia leucotreta (Meyrick) particulièrement au Bénin. Coton et Fibres Tropicales 32, 325-349.

Subbiah, K. (1987) A new host record of a hyperparasite Perilampus sp. (Hymenopetera: Perilampidae) on Apanteles aristaeus Nixon. Current Science 56, 794-796.

Taylor, J.S. (1932) Report on cotton insect and disease investigations. Part II. Notes on the American bollworm (Heliothis obsoleta Fabr.) on cotton, and its parasite, Microbracon brevicronis Wesm. Science Bulletin Department of Agriculture, South Africa No. 113.

Vinson, S.B. (1981) Habitat location, pp. 51-78 in Nordlund, D.A., Jones, R.L. \& Lewis, W.J. (Eds) Semiochemicals: their role in pest control. New York, J. Wiley and Sons.

Waiyaki, J.N. (1973) A new moth of cocoa. FAO Plant Protection Bulletin 21, 117-118.

Weseloh, R.M., Wallner, W.E. \& Hoy, M.A. (1979) Possible deleterious effects of releasing Anastatus kashmirensis, a facultative hyperparasite of the gypsy moth. Environmental Entomology 8, 174-177.

Whitney, W.K. (1970) Observations on maize insects at the International Institute of Tropical Agriculture (IITA) Ibadan. Bulletin of the Entomological Society of Nigeria 2, 101-108.

Accepted 29 March 2002

(C) CAB International, 2002 


\title{
Insect Movement: Mechanisms and Consequences
}

\author{
Edited by I P Woiwod, IACR-Rothamsted, D R Reynolds, NRI, University of Greenwich, and \\ C D Thomas, University of Leeds, UK
}

\author{
April $2001 \quad 464$ pages Hardback \\ ISBN 0851994563 \\ $£ 70.00$ (US\$130.00)
}

Readership: Entomology, animal physiology, behaviour and ecology.

Knowledge of insect movement, particularly of flight, is crucial to our understanding of the great ecological and evolutionary success of insects. The last 20 years have seen many advances in this subject area. New fields have arisen, such as metapopulation theory, and dramatic developments have taken place in methods of studying movement, as a result of new techniques in molecular biology and radar monitoring. There have also been advances in our knowledge of flight-related physiology and behaviour. This book, which is based on the main papers presented at the Royal Entomological Society's 20th Symposium held in September 1999, brings us up to date with these developments.

It contains chapters on:

- flight mechanisms

- foraging movements

- migration

- the evolution of movement strategies

- the interactions between dispersal rates, population structure and gene flow

- the effects of climate change on geographical distribution

It is essential reading for entomologists, and of interest to those researching animal behaviour, physiology, ecology and genetics.

\section{Contents}

Contributors

Preface

- Introduction and overview, I. Woiwood, C D Thomas and D Reynolds

- The biomechanics and functional diversity of flight $R$ Dudley

- How insect wings evolved, $R$ Wootton

- Physiology and endocrine control of flight $G$ Goldsworthy and $M$ Joyce

- Insect behaviours associated with resource finding $J$ Hardie, G Gibson and T Wyatt

- Host location by parasitoids, W Powell and G Poppy

- Flight trajectories of foraging insects: observations using harmonic radar, $J R$ Riley and J L Osborne

- The evolution of migratory syndromes in insects H Dingle

- Migration patterns and orientation mechanisms within the flight boundary layer, $R B$ Srygley and E G Oliveira

CABI Publishing, CAB International,

Wallingford, Oxon, OX10 8DE, UK

Tel:+44(0) 1491832111 Fax:+44(0) 1491829292

Email: orders@cabi.org

CABI Publishing, CAB International,

10 East 40th Street, Suite 3203, New York, NY 10016, USA

Tel:+1 2124817018 Fax:+1 2126867993

Email: cabi-nao@cabi.org
- Characterising the spatial and temporal components of insect migration in inland Australia with novel and traditional methods, V A Drake, $P C$ Gregg et al.

- Significance of habitat persistence and dimensionality in the evolution of insect dispersal strategies

$R$ F Denno, $C$ Grattan and $G$ A Langellotto

- Predation and the evolution of dispersal, $W W$ Weisser

- Evolution of mass transit systems in ants - a tale of two societies, NR Franks

- Dispersal and conservation in heterogeneous landscapes, $N F$ Britton, $G P$ Boswell and $N R$ Franks

- Scale, dispersal and population structure, $C D$ Thomas

- Gene flow, J Mallet

- Use of genetic diversity in movement studies of flying insects, $H D$ Loxdale and $G$ Lushai

- Coping with modern times? Insect movement and climate change, $C$ Parmesan

- Analysing and modelling range changes in UK butterflies, J K Hill, $C D$ Thomas, $R$ Fox, $D$ Moss and B Huntley

Index

For further information or to order please contact CABI Publishing, UK or an exclusive CABI Publishing distributor in your area. For pre-paid orders in the UK, please add $£ 2.75$ for the 1st book and 60p for each additional book ordered (up to max. of 10). For pre-paid orders elsewhere, please add $£ 4.00$ for the 1 st book and $£ 1.00$ for each additional book. For orders not pre-paid, postage and packing will be charged according to the weight of the book. 